\title{
An empirical investigation on how social responsibility changes between public and private organizations
}

\author{
Ali Rashidpour ${ }^{\mathrm{a}}$ and Rasool Sarihi Asfestani ${ }^{\mathrm{b}}$
}

${ }^{a}$ Assistant Professor of Islamic Azad University_Isfahan Science \& Research Branch, Isfahan, Iran

${ }^{b}$ PH.D student of Public management, Islamic Azad University_Isfahan Science \& Research Branch, Isfahan and Chief Accountant of the Ministry of Economic and asset Affairs, Iran

\section{H R O N I C L E}

Article history:

Received May 12, 2013

Received in revised format

20 June 2013

Accepted 25 June 2013

Available online

June 272013

Keywords:

Social responsibility

Environmental activities

Charity activities

Public sector

Private sector

\section{Introduction}

Social policy-making is generally shaped in various forms and by different organizations. The government, social institutions, multinational corporations, and organizations with financial-trade activities are influencing actors of social policy-making process (Joohnson, 2010). Investigating the previous researches on social responsibility show that the researches in this field further tend to investigate the behaviors associated with social responsibility as an independent variable. This factor, in terns, leads to the firm's advantages (e.g., Aupperle et al., 1985; Berman et al., 1999; Campbell, 2007; Hiss, 2009).

*Corresponding author.

E-mail addresses: alireza.mosayebi88@gmail.com (R. S. Asfestani)

\begin{abstract}
A B S T R A C T
Organization theory often focuses on stakeholders' interests as well as the organization's social responsibility and while the focus is normally more on private ganizations, but these issues must be considered in public organizations as well. expect the public organizations to think and to act more generally. The in the field of social responsibility. This is an applied research and is a descriptivesurvey study in terms of research method. The statistical population of this study covers all 670 managers of private and public organizations of city of Tehran, Iran. Using Morgan table and by conducing stratified sampling, a sample size of 140 was selected. Data gathering tool was a questionnaire consisted of 18 items. To confirm the questionnaire validity, we obtained the experts' opinions on acceptable face validy and content validy. To evaluate the questionnaire reliability, the Cronbach's alpha was used (alpha coefficient $=.88$ ). Research hypotheses were tested using independent t-test and all of them were confirmed.
\end{abstract}


They investigated different organizational factors such as norms, rules, and regulations as influencing and shaping factors of social responsibility (willamson et al., 2006), while the macro environmental factors such as governmental variables could also influence the organizations' tendency and activity in the field of social responsibility (Aaronson, 2005; McCrudden, 2006; Moon, 2004). The government is normally one of the main factors influencing social, cultural, political, as well as economic policy-making process (Joohnson, 2010).

However, few studies denote on the effect of macro governmental factors on the firms' social responsibility. When a firm supplies goods or services to government, the firm is further affected by governmental issues because of pre-defined relationship between the seller and buyer, as well as the special governmental rules and regulations in this buying-selling process. There are also higher level of relationship with government especially among governmental organizations, which may cause influence organizations. In other words, when the government is the executer of social responsibility project and tends to act in this field, organizations' rules and regulations are adjusted directly with the government. Furthermore, the influence of these plans is more prominent in such firms owned by the government (Rhodes, 2012). In addition, the private sector consists of different social, economic, and bureaucratic forces. The owners of economic firms, raw material suppliers, vendors, banks, governmental firms, political groups, labor unions, consumers of special products, as well as the units, which are effective in the management of local affairs, are considered in private sector. Therefore, the government is inevitably required to build and sustain the systematic and organized relationships with such units (Robins, 2012).

This study explores the role of government activities in the field of social responsibility and compares their effects on the public and private organizations. The study is based on two theories and concept in the field of social responsibility: Organization theory and theory of the firm. Organization theory suggests that the interests of stakeholders should be more considered, although the organization's social responsibility should be considered too. This mostly applies to private organizations, while both of these factors should be considered together in public organizations. People expect the public organizations to think and act more generally. The governmental policy-makers have an important role in designing these plans and activities (Kidalov, 2011; Knight et al., 2003; Snider \& Rendon, 2008). In addition, those governmental officials that are responsible for direct relationship with firms such as public relations, selling, and buying sections have a critical role in implementing these plans and converting the social responsibility from conceptual to functional state (Monczka et al., 2011; van Weele, 2010). For this purpose, the current study compares the supporting role of government in the field of public and private organizations' social responsibility by designing a questionnaire and comparing the data gathered from the managers of financial, human resources, public relations, and cultural sections.

\section{Literature review}

There are many researches on the firms' social responsibility and most of them are based on four factors proposed by Carroll in 1979 and 1991. These factors are in the four areas of economic (relating to stakeholders), legal (governmental rules and regulations), social (people expectations and charity institutions), and ethical (based on social norms). However, the role of macro governmental factors and the government's supporting role for the organizations that transact directly with the government are not specifically considered.

\subsection{General theories of social responsibility}

The proposed theories of social responsibility are grouped in four categories by Garriga and Mele (2004) as follows,

1) Economic theories with emphasis on financial and profitability aspects of the firms;

2) political theories with emphasis on the firm's power and its responsibility for society; 
3) combined theories defining the social responsibilities based on society demands;

4) ethical theories, which is based on the firm's responsibility for society and general welfare.

To reach the purposes of this study, two theories of agency theory and theory of the firm are considered. Agency theory is associated with a situation in which some stakeholders consign the firm to a specialized person outside their group to manage the organization, more effectively and efficiently (Jensen, 2002; Porter \& Kramer, 2012). A conflict in this relationship appears when the personal objectives of that person may sometimes be in contrast with those of stakeholders (Prahalad \& Hammond, 2002). The stakeholders may look for more profit, while the manager looks for the social prestige. In this way, the manager's personal goals may be in conflict with those of stakeholders (Agle et al., 2008). According to theory of the firm, the organization as a whole is impacted by a bigger organization and environment, and following the orientation of the bigger organization, it has both the formal and informal defined relationships (Hiss, 2009; Shadnam \& Lawrence, 2011). According to Matten and Moon (2008) organizations could act in the two ways: A group of them chooses one or more social affairs based on the circumstances, and the other group tries to accomplish social responsibilities based on the existing rules and regulations. As mentioned earlier, these two theories are the basis of the current study and accordingly, behaviors of the public and private organizations in the field of social responsibility are compared given their relationship with the government as well as the governmental support.

\subsection{General capabilities and pragmatism in the government's social responsibility}

There is always a direct relationship between structural capability and governmental responsibilities. When the government's capability for economic revenues increases, its social responsibility increases consequently. Therefore, there may be a direct relationship between the economic policy-making processes in the field of government's social responsibility and structural capabilities and officials' efficiency. One of the factors that increase the government's capability in economic policy-making is structural and human capabilities issue (Snyder, 2008). In such a process, the government is successful when it creates an appropriate intellectual-analytical framework for utilitarianism mentality in society. This issue is a promotion of pragmatism from the government domain to social sphere. In the economic policy-making process, the government needs to be able to build an appropriate level of social welfare. The structural capability means that the political system needs to create a balance among the individual, group, and class interests called structural equilibrium. Combining these three mentioned components indicates the government's social responsibility concerned with welfare and development, and exploiting the accessible instruments to improve this capability (Urdal, 2012). The government's capability in implementing the development plans as well as doing the social responsibilities and duties means that government is capable of implementing various tool alternatives to reach its objectives. In general, a government without capability is normally faced with much vulnerability. Such a government is not capable of changing the level of social welfare. Although the capability's nature is hybrid and individual, social, and economic components are effective in its realization, a government that is able to operationalize its executive objectives has a high degree of capability (Kinney, 2011). The bankrupt governments are units with low levels of capability and when then fail to recognize their desired objectives or disregard their social responsibilities and duties are not able to properly make economic policies and consequently, lose their position in public opinions. The governments are required to improve their executive capability in social organizational policymaking process. In this regard, the countries have social security if they have the necessary context for accomplishing the government's commitments in the field of social responsibility (Cochrane, 2013). Most of the scholars believe that the government is a major stimulant of social responsibility (Aaronson, 2005; fox et al., 2012; Moon, 2010). Totally, we can consider the four overall roles for the government in the field of social responsibility:

1. Codifying the minimum regulations for organizations in the field of social responsibility,

2. Financial supporting for organizations in the field of social responsibility, 
3. Modeling in the large organizations affiliated with the government such as ministries in the field of social responsibility,

4. Encouraging the organizations that use their social responsibilities properly.

Each of the above cases has been investigated in various regions and by researchers (De laCuestaGonza, 2004; Aaronson, 2005; Albareda et al., 2007). However, few studies have investigated the role of the government's plans and activities in organizations. Given the fact that the government dominates the public and private organizations, we may build an effective and proper pattern of social responsibility in these organizations.

\subsection{Social responsibility in supply management theory}

Many researchers especially in recent decade have investigated the social responsibility in the field of supply management (e.g., Carter \& Jennings, 2000; Leire \& Mont, 2010; Maloni \& Brown, 2006).This theory is associated with this fact that the firms are working before and after the they are located in the regulations, which may influence all the organization's activities. These activities may include the organization's activities and plans in the field of social responsibility (Worthington et al., 2008). Therefore, the supply chain could be considered as an influencing factor of the organization's voluntary and involuntary activities in the field of social responsibility (Reuter et al., 2010).

\subsection{Social responsibility in the theory of public support}

Good governance is one of the most necessary subjects of the countries' social and economic policymaking. It will be achieved when a constructive and cooperative relationship forms among the government, private sector, and executive institutions. The government's social responsibility towards the private companies is not merely responding to their economic needs (Manson, 2011).

The existence of some indicators implies that the organizations' social responsibility in the years after the Second World War is steadily increased. The global large and prestigious firms feel more responsibility towards their social, cultural, and political issues. Many economic, cultural, and academic establishments in the U.S. are achieved through multinational firms' investments, and so, the signs of cooperation and solidarity of various economic-social layers can be observed in the shared responsibility process of the government and private organizations. This is accomplished to improve the accessible resources of the social groups (Cochrane, 2013).

Given the government's vastness and its legal and executive ability to influence the activities and plans of the public and private firm, it can be said that the government could be the most influencing factor of the private and public firms in the field of social responsibility (McCrudden, 2006). Furthermore, few studies indicate on effect of the government's supporting plans on public and private organizations. Since the government's role is to lead and to control the private companies, the approved decisions and laws play the guidance role for private sector. This issue states that the nature of the government's social responsibility is sometimes authoritarian (McCrudden, 2013). The important influencing factor of the social responsibility's plans and activities is known to be the governmental rules and regulations by the public organizations (e.g., Brammer \& Walker, 2007; Walker \& Brammer, 2009; Oldroyd et al., 2011). In addition, one important factor for private organizations is their reputation and fame, which is an affective stimulant towards their social activities (Walker \& Philips, 2009). By reviewing the previous studies, we may understand there are many researches on the government's supporting role in forming a special pattern of social responsibility in the organizations.

\subsection{The government's social responsibility modeling in the organizations}

The government propagates the firms' social responsibility in three different ways: by legislation for determining the minimum of social responsibility in all firms, by encouraging the firms to engage in 
this field, and by defining a framework for firms transacting with the government directly (Davis, 2004). The government is capable of forcing the public and private organizations to perform the social activities using the contracts of sale or purchase of goods or services, in such a way to choose a firm in which the social responsibility is an important component (Cochrane, 2013). The government may wish to internalize the social responsibility in the organizations under any conditions. In such a case, it can force the public and private firms to act based on approved rules and regulations (Federal Acquisition Regulation, 2011).

\subsection{Private sector and social responsibility}

One of the things which is important for the national governance as well as the global governance is that how much the government's responsibility is devoted to the private sector. In addition, how much the private sector responsibility is to the government, social groups, and general layers of the society. These issues show that handling of the global affairs as well as controlling the countries' internal structure is impossible without solidarity and cooperation of the various groups (Cochrane, 2013).

One of the main social responsibility fields of the government in social policy-making is to support the private firms (snyder, 2008). Private sector, internal organizations, and international corporations are responsible for social, political, and economic fields as much as the government is. In the Unites States, the private sector is accounted as one of the main centers of supporting the social groups and providing the educational, health, and cultural services. The reason for this, is the economic capability promotion and social impacting of such units in the international system (Barry, 2011).

\subsection{Social responsibility increasing during the contract}

The government acts as a catalyst in the countries located in the south of the Persian Gulf and plays the supporting impact on the private sector. This means that the government's social responsibility to the private sector is broad and extensive in such countries. The catalyst governments of the social responsibility to the private sector adopt a supporting approach and provide the necessary facilities for economic and social activities of these units. In such circumstances, the government is looking to make some policies in encouraging the technologic innovations in social and economic fields. By adopting these policies, the circumstances are provided for the public and private firms to enhance their activities. In other words, the government treats this situation as its ethical responsibility to support the private sector beyond the general rules of the country in order to improve its technologic, economic, and financial capabilities (Worthington, 2000).

In this catalyzing process, some of the restrictive social and economic regulations are disregarded. On the other hand, some new economic and social regulations are being approved, which provide better conditions for relationship between the government and private firms and causes these relationships to be relationally transparent. Communicational transparent and increasing cooperative relationships build the common and complementary responsibility between the government and private sector (Urdal, 2012). As mentioned previously, one important way for the government's attention to social issues is to enact the appropriate regulations when contracting with private and public firms or when investigating their proposal or initial plan. The government should make an assessment on the firms' social responsibility along with other factors such as quality, cost-benefit, etc. In the past, the issue of quality or parties' advantages especially when the government was contracting with a public or private organization was very important and obligatory. Researches in developed countries indicate that this trend is shifting towards the importance of social issues and environmental ones more specifically (Matten \& Moon, 2008). Also in Iran, one of the most important factors for activity permit is to consider the environmental issues especially when establishing a new company, organization, or a manufacturing factory. In this study, we investigate the effect of governmental support and regulations on social responsibility of public and private organizations given the role of mandatory rules as well as the voluntary activities of these firms concerning the social and environmental issues. 
As explained earlier, the supporting role of the government in the field of social responsibility is compared between the public and private organizations in terms of economic, legal, and ethical.

Hypothesis 1: the public organization's economic tendency to social and environmental activities is greater than the private organizations.

Hypothesis 2: the public organization's legal tendency to social and environmental activities is greater than the private organizations.

Hypothesis 3: the public organization's ethical tendency to social and environmental activities is greater than the private organizations.

\section{Research method}

The current study is an applied research and is a descriptive survey in terms of nature and method. The statistical population is comprised of all 670 managers of public and private organizations in city of Tehran, Iran in 2012. The sample size of 240 was selected according to Morgan table and using stratified sampling. We used the library and field methods in order to realize the organizations' features in the field of social responsibility and to interpret and understand these features. Data gathering tool was a questionnaire consisted of 18 items with a 5-point Likert-type scale ranging from " 1 =very low" to " $5=$ very much". The opinions of experts were obtained to confirm the questionnaire validity indicating its acceptable content and face validity. The Cronbach's alpha was used to measure the questionnaire reliability (alpha coefficient was .88). We used descriptive statistics (frequency and frequency percentage) to describe the data, and inferential statistics (independent t-test) to investigate the differences between public and private organizations.

\section{Findings}

\subsection{Descriptive analysis}

This section attempts to analyze the statistical results of t-test as well as to study the participants' demographics. Hence, the participants' demographics consisted of gender, age, organizational department, and educational level are investigated. In our survey, 52 participants were female and the other 92 were male. In addition, 34 surveyed people were from public relations, 41 were enrolled in human resources, 46 were working in marketing 29 people were working in research and development. In terms of educational background, 19 participants only finished high schools, 61 hole bachelor of sciences, 42 finished masters degrees and 28 of them hold PhD degrees. Finally, 40 people were less than 30 years old, 61 between 31-40 and 49 people were more than 41 years old.

\subsection{Inferential analysis}

In order to examine the research hypotheses and to compare the obtained averages with each other, the independent test was used.

The main hypothesis: there exists a significant difference between the attitudes of the managers of public and private organizations in terms of social responsibility. The independent t-test was used to analyze this question and Table 1 demonstrates the results of our survey.

\section{Table 1}

Mean and standard deviation of the managers of public and private organizations' attitudes in terms of social responsibility

\begin{tabular}{ccccc}
\hline Type of organization & $\mathrm{N}$ & mean & Standard deviation & Mean standard deviation \\
\hline public & 75 & 3.5274 & 0.36572 & 0.04223 \\
private & 75 & 3.2584 & 0.39166 & 0.04523 \\
\hline
\end{tabular}


Table 2

$\mathrm{t}$-test in order to compare the means

\begin{tabular}{cccccccccc}
\hline Equal variance & $\mathrm{F}$ & Sig. & $\mathrm{t}$ & $\mathrm{df}$ & $\begin{array}{c}\text { Sig. } \\
\text { (2-tailed) }\end{array}$ & Mean & \multicolumn{2}{c}{ Std. Error } & \multicolumn{2}{c}{ 95\% Confidence } \\
& & & & & 0.258 Difference $^{2}$ & Lower & Upper \\
\hline Assumed & 6.964 & 0.009 & 1.139 & 148 & 0.256 & 0.06889 & 0.06049 & -0.05065 & 0.18843 \\
Not assumed & & & 1.139 & 138.302 & 0.257 & 0.06889 & 0.06049 & -0.5072 & 0.18850 \\
\hline
\end{tabular}

As we can observe from the results of Table 2, Levene's F statistic with the value of .729 indicates that the groups' variance is heterogeneous, so the conservative $t$ is being used in order to compare the groups. In addition, $t$ statistic with the value of 4.374 and freedom degree of 148 indicated that the difference between the public and private organizations is statistically significant at the confidence level of .99. The bottom and top limits are both positive indicating a significant difference between the managers of public and private organizations in terms of social responsibility. In addition, the difference value indicates that the amount of this variable is higher in the public section.

\subsection{Subsidiary hypotheses}

First hypothesis: the public organization's economic tendency to social and environmental activities is greater than the private organizations.

Independent t-test is used in order to analyze this question.

\section{Table 3}

Mean and standard deviation of managers of the public and private organizations' economic tendency towards the social and environmental activities

\begin{tabular}{ccccc}
\hline Type of organization & $\mathrm{N}$ & mean & Standard deviation & Mean standard deviation \\
\hline public & 75 & 3.1383 & 0.57605 & 0.07993 \\
private & 75 & 3.5000 & 0.68756 & 0.06652 \\
\hline
\end{tabular}

\section{Table 4}

t-test in order to compare the means

\begin{tabular}{|c|c|c|c|c|c|c|c|c|c|}
\hline \multirow{2}{*}{ Equal variance } & \multirow[b]{2}{*}{$\mathrm{F}$} & \multirow[b]{2}{*}{ Sig. } & \multirow[b]{2}{*}{$\mathrm{t}$} & \multirow[b]{2}{*}{$\mathrm{df}$} & \multirow{2}{*}{$\begin{array}{c}\text { Sig. } \\
\text { (2-tailed) }\end{array}$} & \multirow{2}{*}{$\begin{array}{c}\text { Mean } \\
\text { Difference }\end{array}$} & \multirow{2}{*}{$\begin{array}{c}\text { Std. Error } \\
\text { Difference }\end{array}$} & \multicolumn{2}{|c|}{ 95\% Confidence Interval } \\
\hline & & & & & & & & Lower & Upper \\
\hline Assumed & 1.618 & 0.205 & 3.483 & 147 & 0.001 & 0.36171 & 0.10381 & 0.15646 & 0.56692 \\
\hline Not assumed & & & 3.478 & 141.950 & 0.001 & 0.36171 & 0.10398 & 0.15615 & 0.56727 \\
\hline
\end{tabular}

As it can be seen from Table 4, F statistic with the value of 1.618 indicates that the groups' variance is heterogeneous, so the conservative $t$ is being used in order to compare the groups. In addition, $t$ statistic with the value of 4.483 and freedom degree of 147 has indicated that the difference between the public and private organizations is statistically significant at the confidence level of .99. The bottom and top limits are both positive indicating a significant difference between the managers of public and private organizations in terms of economic tendency. In addition, the difference value indicates that the amount of this variable is higher in the private section.

Second hypothesis: the public organization's legal tendency to social and environmental activities is greater than the private organizations.

Independent t-test is used in order to analyze this question.

\section{Table 5}

Mean and standard deviation of managers of the public and private organizations' legal tendency towards the social and environmental activities

\begin{tabular}{ccccc}
\hline Type of organization & N & mean & Standard deviation & Mean standard deviation \\
\hline Public & 75 & 3.4178 & 0.31762 & 0.03668 \\
Private & 75 & 3.3489 & 0.41660 & 0.04810 \\
\hline
\end{tabular}




\section{Table 6}

t-test in order to compare the means

\begin{tabular}{|c|c|c|c|c|c|c|c|c|c|}
\hline \multirow[t]{2}{*}{ Equal variance } & \multirow[b]{2}{*}{$\mathrm{F}$} & \multirow[b]{2}{*}{ Sig. } & \multirow[b]{2}{*}{$\mathrm{t}$} & \multirow[b]{2}{*}{ df } & \multirow{2}{*}{$\begin{array}{c}\text { Sig. } \\
\text { (2-tailed) }\end{array}$} & \multirow{2}{*}{$\begin{array}{c}\text { Mean } \\
\text { Difference }\end{array}$} & \multirow{2}{*}{$\begin{array}{l}\text { Std. Error } \\
\text { Difference }\end{array}$} & \multicolumn{2}{|c|}{$\begin{array}{l}\text { 95\% Confidence } \\
\text { Interval }\end{array}$} \\
\hline & & & & & & & & Lower & Upper \\
\hline assumed & 6.964 & 0.009 & 1.139 & 148 & 0.256 & 0.06889 & 0.06049 & -0.05065 & 0.18843 \\
\hline not assumed & & & 1.139 & 138.302 & 0.257 & 0.06889 & 0.06049 & -0.5072 & 0.18850 \\
\hline
\end{tabular}

As it can be seen in above table, F statistic with the value of 6.964 indicates that the groups' variance is homogeneous, so the t statistic is being used in order to compare the groups.

As it can be seen in above table, t statistic with the value of 1.139 and freedom degree of 138 indicated that the difference between the public and private organizations is not statistically significant at the confidence level of .99. The bottom and top limits are both positive indicating there is not a significant difference between the managers of public and private organizations in terms of legal tendency to social and environmental activities.

Third hypothesis: the public organization's ethical tendency to social and environmental activities is greater than the private organizations.

Independent t-test is used in order to analyze this question.

\section{Table 7}

Mean and standard deviation of managers of the public and private organizations' ethical tendency towards the social and environmental activities

\begin{tabular}{lcccc}
\hline Type of organization & $\mathrm{N}$ & mean & Standard deviation & Mean standard deviation \\
\hline Public & 75 & 3.6644 & 0.55038 & 0.06355 \\
Private & 75 & 3.2911 & 0.70716 & 0.08116 \\
\hline
\end{tabular}

\section{Table 8}

t-test in order to compare the means

\begin{tabular}{cccccccccc}
\hline \multirow{2}{*}{ Equal variance } & & & & & & & \multicolumn{3}{c}{$95 \%$ Confidence } \\
& & & & & Sig. & Mean & \multicolumn{2}{c}{ Std. Error } & \multicolumn{2}{c}{ Interval } \\
& F & Sig. & t & df & (2-tailed) & Difference & Difference & Lower & Upper \\
\hline assumed & 5.396 & 0.022 & 3.608 & 148 & 0.000 & 0.37333 & 0.10347 & 0.16886 & 0.57781 \\
not assumed & & & 3.608 & 139.58 & 0.000 & 0.37333 & 0.10347 & 0.16886 & 0.57791 \\
\hline
\end{tabular}

According to the results of Table 8, F statistic with the value of 5.396 indicates that the groups' variance is homogeneous, so the conservative $t$ is being used in order to compare the groups. In addition, t statistic with the value of 3.608 and freedom degree of 139 indicated that the difference between the public and private organizations is statistically significant at the confidence level of .99. The bottom and top limits are both positive indicating a significant difference between the managers of public and private organizations in terms of ethical tendency to social and environmental activities. Besides, the difference value indicates that the amount of this variable is higher in the public section.

\section{Conclusion}

In this study, after explaining social responsibility, social activities, and voluntary activities in terms of economics, legislation, and ethics we comparatively investigated them amongst the managers of public and private organizations. To reach this goal, related literature was investigated and finally, the research conceptual framework was formed. In the following, the research hypotheses were tested using the statistical techniques mentioned in the findings section. The results were as follows:

The main hypothesis suggested that there was a significant difference between the managers' attitudes of the public and private organizations in terms of social responsibility and the results of our survey have confirmed this hypothesis. First sub-hypothesis suggested that the economic tendency of the public organizations in terms of social and environmental activities is greater than the private ones 
and the results of our survey confirmed thus hypothesis. The second sub-hypothesis indicated that legal tendency of the public organizations in terms of social and environmental activities was greater than the private ones and the results of our survey have indicated that the average of this variable was identical between the managers of the public and private sectors. Thus, the tendency of both groups of the managers to social and environmental activities is equal. Finally, the third hypothesis indicated that voluntary and ethical tendency of the public organizations in terms of social and environmental activities was greater than the private ones. Results for this hypothesis have indicated that the managers of the public sector are more intent to social and environmental activities and the average value of this variable was more for the public managers.

\section{References}

Aaronson, S. (2005). "Minding our business"': what the United States government has done and can do to ensure that U.S. multinationals act responsibly in foreign markets. Journal of Business Ethics 59, 175-198.

Agle, B., Donaldson, T., Freeman, R., Jensen, M., Mitchell, R., \& Wood, D., (2008). Dialogue: toward superior stakeholder theory. Business Ethics Quarterly 18, 153-190.

Albareda, L., Lozano, J., \& Ysa, T. (2007). Public policies on corporate social responsibility: the role of governments in Europe. Journal of Business Ethics, 74, 391-407.

Alcock, P., May, M., \& Wright, S. (Eds.). (2011). The student's companion to social policy. WileyBlackwell.

Aupperle, K., Carroll, A., \& Hatfield, J. (1985). An empirical examination of the relationship between corporate social responsibility and profitability. Academy of Management Journal, 28, 446-463.

Barry, B. (1999). The study of politics as a vocation. The British study of politics in the twentieth century, 425-67.

Berman, S., Wicks, A., Kotha, S., \& Jones, T. (1999). Does stakeholder orientation matter? The relationship between stakeholder management models and the firm financial performance. Academy of Management Journal, 42, 488-509.

Brammer, S., \& Walker, H. (2007). Sustainable procurement practice in the public sector: An international comparative study.

Campbell, J. (2007). Why would corporations behave in socially responsible ways? An institutional theory of corporate social responsibility. Academy of Management Review, 32, 946-967.

Carroll, A. (1979). A three-dimensional conceptual model of corporate performance. Journal of Business Ethics, 15, 927-939.

Carroll, A. (1991). The pyramid of corporate social responsibility: Toward the moral management of organizational stakeholders. Business Horizons 34, 240-246.

Carter, C. R., \& Jennings, M. (2000). Purchasing's Contribution to the Socially Responsible Management of the Supply Chain. Tempe, AZ: Center for Advanced Purchasing Studies.

Cochrane, A. (2013). The governance of local Welfare, in P. Alacock, A. Erskine and M.

Davis, K. (1975). Five propositions for social responsibility. Business Horizons, 18(3), 19-24.

González, M. D. L. C., \& Martinez, C. V. (2004). Fostering corporate social responsibility through public initiative: from the EU to the Spanish case. Journal of Business Ethics, 55(3), 275-293.

Federal Acquisition Regulation. (2011). From Federal Acquisition Regulation. Garriga, E., \& Melé, D. (2004). Corporate social responsibility theories: mapping the territory. Journal of business ethics, 53(1-2), 51-71.

Hiss, S. (2009). From implicit to explicit corporate social responsibility. Business Ethics Quarterly, 19(3), 433-451.

Jensen, M. (2002). Value maximization, stakeholder theory, and the corporate objective function. Business Ethics Quarterly, 12, 235-256.

Joohnson, N. (2010) The Welfare State in Transition: the Theory and Practice of Welfare Pluralism, Brighton: Wheal sheaf. 
Kidalov, M. (2011). Small business contracting in the United States and Europe: a comparative assessment. Public Contract Law Journal, 40, 443-509.

Kinney, William. (2011), Social Rights and Economics, London: Routledge

Knight, L., Caldwell, N., Harland, C., \& Telgren, J. (2003). Government reform and public procurement: Academic report of the first workshop. International Research Study of Public Procurement. From. Retrieved, 2(11).

Leire, C., \& Mont, O. (2010). The implementation of socially responsible purchasing. Corporate Social Responsibility and Environmental Management 17, 27-39.

Maloni, M., \& Brown, M. ( 2006). Corporate social responsibility in the supply chain: an application in the food industry. Journal of Business Ethics, 68, 35-52.

Manson, J. (2011). The social Attitudes of Management, Englewood Cliffs, N.J: Prentice - Hall.

Matten, D., \& Moon, J. (2008). Implicit and explicit CSR: a conceptual framework for a comparative understanding of corporate social responsibility. Academy of Management Review, 33, 404-424.

McCrudden, C., (2007). Buying social Justice: Equality, Government Procurement, and Legal Change. Oxford University Press, New York.

McCrudden, C. (2007). Corporate social responsibility and public procurement.

Monczka, R., Handfield, R., Giunipero, L., \& Patterson, J. (2011). Purchasing and Supply Management, $5^{\text {th }}$ ed. South-Western Cengage Learning, Mason, $\mathrm{OH}$.

Moon, J., (2010).Government as a Driver of Corporate Social Responsibility. Research Paper no. 202004. International Centre for Corporate Social Respon-sibility, Nottingham University Business School.

Oldroyd, C., Grosvold, J., \& Millington, J. (2011). Advantages and disadvantages of socially and environmentally sustainable procurement practices in the public and private sectors: An empirical investigation. In: Proceedings of 20th International Purchasing and Supply Education and Research Conference, Maastricht, the Netherlands, April 10-13.

Porter, M., \& Kramer, M. (2012).The competitive advantage of corporate philan- thropy. Harvard Business Review 80, 56-69.

Prahalad, C., \& Hammond, A. (2002). Serving the world's poor, profitably. Harvard Business Review, 80, 48-58.

Reuter, C., Foerstl, K., Hartmann, E., \& Blome, C. (2010). Sustainable global supplier management: the role of dynamic capabilities in achieving competitive advantage. Journal of Supply Chain Management, 46, 45-63.

Rhodes, M., (2012).Whose Trojan horses?. International Journal, 57, 631-637.

Robins, I. (2012), Understanding Sense Capability Approach, Cambridge: Cambridge University Press.

Shadnam, M., \& Lawrence, T. (2011).Understanding widespread misconduct in organizations. Business Ethics Quarterly 21, 379-407.

Snider, K., \& Rendon, R., (2008). Public procurement policy: implications for theory and practice. Journal of Public Procurement 8, 310-333.

Snyder, J. (2008), From Voting to Violence: Democratization and Nationalist Conflict. New York, NY: Norton.

Urdal, H. (2012). The Devil in the Demographics. The Effect of Youth Bulges

vanWeele, A., (2010). Purchasing and Supply Chain Management, $5^{\text {th }}$ ed. Cengage Learning, Andover, Hampshire, U.K..

Walker, H., \& Brammer, S. (2009).Sustainable procurement in the UK public sector. Supply Chain Management: An International Journal 14, 127-138.

Wantchekon, L. (2000), why do Resource Dependent Countries Have Authoritarian Governments. New Haven: Yale University Press. Welfare Pluralism, Brighton: Wheal sheaf.

Worthington, I., Ram, M., Boyal, H., \& Shah, M. (2008).Researching the drivers of socially responsible purchasing: a cross-national study of supplier diversity initiatives. Journal of Business Ethics, 79, 319-331. 